\title{
Systematic Review Faktor Faktor Yang Dapat Meningkatkan Kemampuan Guru Berpikir Tingkat Tinggi
}

\author{
${ }^{1}$ Mahatma, ${ }^{2}$ Yetti Supriyati \\ ${ }^{1}$ Pendidikan Ekonomi Universitas Pancasakti Bekasi \\ ${ }^{2}$ Penelitian dan Evaluasi Pendidikan Pascasarjana Universitas Negeri Jakarta \\ Email: muhamad.mahatma@gmail.com, yeti.supriyati@unj.ac.id
}

\begin{abstract}
This study aims to identify what factors are a problem or a barrier for teachers to develop higher order thinking skills and what factors can improve teachers' higher order thinking skills. This research is a Systematic Review using the Preferred Reporting Items for Systematic Review and Meta Analyzes (PISMA) method. The results of the study identified several factors that hindered teachers from higher order thinking. With these results, it is hoped that teachers and related parties can focus on improving themselves on factors that can increase the ability of teachers to think at higher levels.
\end{abstract}

Keywords: Systematic Review, Teacher ability, HOTS.

Abstrak. Penelitian ini bertujuan untuk untuk mengidentifikasi faktor faktor apakah yang menjadi masalah atau hambatan bagi guru untuk mengembangkan kemampuan berpikir tingkat tinggi dan faktor faktor apakah yang dapat meningkatkan kemampuan guru berpikir tingkat tinggi. Penelitian ini merupakan Systematic Review dengan menggunakan metode Preferred Reporting Items for Systematic Review and Meta Analyses (PISMA). Hasil penelitian mengidentifikasikan beberapa faktor yang menjadi hambatan guru untuk dapat berpikir tingkat tinggi. Dengan hasil ini diharapkan guru dan pihak terkait dapat focus untuk meningkatkan diri pada faktor faktor yang dapat meningkatkan kemampuan guru untuk berpikir tingkat tinggi.

Kata Kunci : Systematic Review, Kemampuan guru, HOTS.

\section{PENDAHULUAN}

Partnership of $21^{\text {st }}$ Century Skill telah menjabarkan bahwa ketrampilan yang harus dimiliki oleh siswa di abad 21 adalah keterampilan yang dapat membuat siswa mengembangkan kompetensinya secara optimum. Kompetensi seperti berfikir kritis untuk memecahkan masalah, mampu berkomunikasi dengan baik, mampu mengikuti perkembangan teknologi, kemampuan literasi media dan informasi (Basuki \& Haryanto, 2012) internasional Programme for International Student Assessment (PISA) telah menunjukkan pada kita bahwa reading literacy, mathematical literacy, scientific literacy yang dimiliki oleh siswa kita sangat rendah. Kemampuan siswa Indonesia biasanya sangat rendah dalam: (1) memahami data yang sulit dan saling berhubungan; (2) analisia dan pemecahan masalah; (3) penggunaan media dan tahapan dalam memecahan masalah; dan (4) melakukan penelitian dan percobaan (Kemendikbud, 2017; P, Suryanda, \& W, 2018).
Kemampuan berpikir tingkat tinggi (higher order thinking skills) merupakan suatu kemampuan berpikir yang tidak sekedar ingatan, mengemukakan kembali dan membaca dan menceritakan kembali (Kemendikbud, 2017). Higher order thinking skills (HOTS) atau keterampilan berpikir tingkat tinggi merupakan bagian dari taksonomi Bloom hasil revisi yang berupa kata kerja operasional yang terdiri dari analyze (C4), evaluate (C5) dan create (C6) yang dapat digunakan dalam penyusunan soal. Guru harus memiliki pengetahuan dan keahlian untuk menunjang pekerjaannya, sehingga dapat mengembangkan keterampilan berpikir tingkat tinggi peserta didik tingkat SMA (Aydin \& Yilmaz, 2010)

HOTS adalah keterampilan tingkat lanjut yang lebih dari sekadar mengingat dan menghafal materi pelajaran (Widana, 2017, Ahmad, dkk, 2019). Sedangkan tujuan pembelajaran berbasis HOTS hanya akan tercapai jika guru berperan serta dalam perencanaan, pelaksanaan, dan evaluasi berbasis pembelajaran HOTS (Sudjiono, 2013). Artinya guru berperan penting 
untuk merencanakan, melaksanakan, dan mengevaluasi proses untuk meningkatkan keterampilan berpikir tingkat tinggi siswa. Namun, guru sekolah dasar mengalami kesulitan dalam merancang asesmen (Suratmi, Laihat, Asnimar, \& Handini, 2020). Mereka tahu bahwa HOTS terintegrasi Kurikulum 2013 tetapi butirbutirnya tidak mewakili HOTS sama sekali. Hal ini sedikit banyak mengisyaratkan pada kita bahwa bukan hanya kemampuan berpikir tingkat tinggi pada siswa saja yang diutamakan, namun kemampuan guru dalam berpikir tingkat tinggi juga harus diperhatikan.

Dengan menggunakan aplikasi VosViewer dapat diketahui bahwa telah begitu banyak penelitian tentang High Order Thinking Skill, namun penelitian tersebut lebih berfokus pada kemampuan siswa berpikir tingkat tinggi. Bahkan belum ada penelitian systemtical review tentang kemampuan guru berpikir tingkat tinggi. Penelitian ini akan menelaah dari beberapa sumber untuk mengidentifikasi faktor faktor apakah yang menjadi masalah atau hambatan bagi guru untuk mengembangkan kemampuan berpikir tingkat tinggi dan faktor faktor apakah yang dapat meningkatkan kemampuan guru berpikir tingkat tinggi. Sehingga dengan adanya kajian systematic review ini para guru maupun pihak yang terkait dapat meningkatkan kemampuannya dalam berpikir tingkat tinggi.

\section{METODE}

Penelitian ini merupakan Systemaic Review dengan menggunakan metode Preferred Reporting Items for Systematic Review and Meta Analyses (PISMA). Tahapan - tahapan dalam penelitian ini terdiri dari : 1) Initial Search, 2) Records after Duplicate Remove, 3) Record Screened (Titles and Abstract), 4) Full Text Article Assessed for Eligibility , 5) Studies include in Narative Analysis (Joypaul S, Kelly F, McMillan SS, King) MA (2019)).

Penelitian ini dilaksanakan pada bulan Januari 2021 di Jakarta. Pencarian artikel penelitian yang relevan dilakukan dengan menggunakan kata kunci kemampuan guru berpikir tingkat tinggi.

Proses pencarian jurnal difokuskan pada jurnal yang membahas kemampuan guru berpikir tingkat tinggi. Pencarian jurnal dilakukan dengan bantuan applikasi pencari jurnal seperti ScienceDirect, ERIC, Google Scholar dan Google Cendikia. Dari hasil pencarian melalui Scienedirect diperoleh 1642 artikell, dari ERIC diperoleh 307 artikel, dan dari Google Scholar diperoleh 1400 artikel. Kemudian artikel artikel diseleksi, artikel yang sama kemudian disisihkan dan diseleksi kembali melalui judul artikel dan abstrak. Sehingga kemudian diperoleh 10 artikel.

\section{HASIL DAN PEMBAHASAN}

Hasil dari data penelitian yang dimasukkan dalam penelitian ini adalah sebagai berikut:

Pada tabel 2 terlihat bahwa jenis penelitian yang digunakan peneliti pada artikel jurnal yang dianalisis adalah Penelitian Tindakan, Kualitatif, Studi Komparatif, Penelitian Survey, Mixed Method dan RND. Berdasarkan analisis data diperoleh bahwa jenis penelitian yang paling banyak dilakukan adalah Penelitian Tindakan dengan frekwensi relative $40 \%$. Penelitian Tindakan dilakukan agar dapat dimanfaatkan untuk meningkatkan kemampuan guru melakukan refleksi diri, meningkatkan kemajuan sekolah, dan menumbuhkan budaya profesional di kalangan pendidik.

Tabel 1. Distribusi Artikel Subjek Penelitian

\begin{tabular}{|c|c|c|c|c|c|}
\hline No & Peneliti & Jenis Penelitian & Studi & Jenjang & g Faktor Faktor \\
\hline 1. & Yuli Nurul Fauziah & Studi Komparatif & IPA & SD & $\begin{array}{l}\text { Kemampuan berpikir } \\
\text { kreatif }\end{array}$ \\
\hline 2. & $\begin{array}{l}\text { Endah Budi Rahaju, } \\
\text { Dini Kinati Fardah, } \\
\text { Pradnyo Wijayanti, }\end{array}$ & Penelitian Kualitatif & Matematika & SMP & $\begin{array}{l}\text { Kemampuan berpikir } \\
\text { abstrak }\end{array}$ \\
\hline 3. & $\begin{array}{l}\text { Ismail } \\
\text { Nurul Laila }\end{array}$ & Penelitian Tindakan & PKn, IPS & SMP & Kemampuan \\
\hline 4. & $\begin{array}{l}\text { Yunita Sari; } \\
\text { Andarini Cahyaningtyas; } \\
\text { Mega M Maharani; } \\
\text { Sari Yustiana; }\end{array}$ & Penelitian Tindakan & IPA & $\mathrm{SD}$ & $\begin{array}{l}\text { Pemecahan masalah } \\
\text { Kemauan untuk } \\
\text { mengembangkan } \\
\text { diri }\end{array}$ \\
\hline 5. & $\begin{array}{l}\text { Rida F Kusumadewi } \\
\text { Imam Safi'i, } \\
\text { Wini Tarmini, } \\
\text { Sobri }\end{array}$ & Penelitian Tindakan & & SMP & $\begin{array}{l}\text { Kemampuan } \\
\text { Pemahaman }\end{array}$ \\
\hline 6. & $\begin{array}{l}\text { Ade Suryanda } \\
\text { Eka Putri Azrai, } \\
\text { Tinia Leyli Shofia Ahmad, } \\
\text { Zubaidah, } \\
\text { Evi Suryani }\end{array}$ & Penelitian Tindakan & Biologi & MAN & $\begin{array}{l}\text { Kemampuan } \\
\text { menyelesaikan } \\
\text { masalah }\end{array}$ \\
\hline 7. & Femmy Kawuwung & Deskriptif Kualitatif & IPA & SMP & Kemampuan Inqury \\
\hline 8. & $\begin{array}{l}\text { Dodi Iskandar, } \\
\text { Senam }\end{array}$ & Penelitian Survey & Kimia & SMA & Kualitas Guru \\
\hline 9. & Akarat Tanak & $\begin{array}{l}\text { concurrent mixed } \\
\text { Methods }\end{array}$ & Science & $\begin{array}{l}\text { Pre } \\
\text { Service }\end{array}$ & $\begin{array}{l}\text { Inquiry Teaching } \\
\text { Ability }\end{array}$ \\
\hline 10. & $\begin{array}{l}\text { Candra Utama } \\
\text { Sajidan } \\
\text { Joko Nurkamto } \\
\text { Wiranto }\end{array}$ & RND & Biology & & Logical Ability \\
\hline \multicolumn{6}{|c|}{ Tabel 2. Jenis Penelitian } \\
\hline No & Jenis Penelitian & & Frekwensi & & Frekwensi Relatif \\
\hline 1. & Penelitian Tindakan & & 4 & & $40 \%$ \\
\hline 2. & Kualitatif & & 2 & & $20 \%$ \\
\hline 3. & Studi Komparatif & & 1 & & $10 \%$ \\
\hline 4. & Penelitian Survey & & 1 & & $10 \%$ \\
\hline 5. & Mixed Method & & 1 & & $10 \%$ \\
\hline 6. & R N D & & 1 & & $10 \%$ \\
\hline
\end{tabular}

Tabel 3. Faktor - Faktor yang menjadi masalah bagi guru

$$
\begin{aligned}
& \text { Faktor - Faktor } \\
& \text { Kemampuan Pemecahan Masalah } \\
& \text { Kemampuan Inquiry } \\
& \text { Kemampuan berpikir kreatif } \\
& \text { Kemampuan berpikir abstrak } \\
& \text { Kemampuan Pemahaman } \\
& \text { Kemampuan berfikir logis } \\
& \text { Kemauan mengembangkan diri } \\
& \text { Kualitas Guru }
\end{aligned}
$$

$\begin{array}{ll}\text { Frekwensi } & \text { Frekwensi Relatif } \\ 2 & 20 \% \\ 2 & 20 \% \\ 1 & 10 \% \\ 1 & 10 \% \\ 1 & 10 \% \\ 1 & 10 \% \\ 1 & 10 \% \\ 1 & 10 \%\end{array}$


Adapun hasil analisis yang berkaitan dengan faktor faktor yang menjadi masalah bagi guru untuk mengembangkan kemampuan berpikir tingkat tinggi dapat dilihat di tabel 3 . Pada tabel 3 terlihat bahwa faktor faktor yang menjadi masalah bagi guru untuk mengembangkan kemampuan berpikir tingkat tinggi adalah rendahnya Kemampuan Pemecahan Masalah, Kemampuan Inquiry, Kemampuan berpikir kreatif, Kemampuan berpikir abstrak, Kemampuan Pemahaman, Kemampuan berfikir logis, Kemauan mengembangkan diri, dan Kualitas Guru. Faktor faktor yang paling banyak menjadi masalah bagi guru untuk mengembangkan kemampuan berpikir tingkat tinggi adalah rendahnya kemampuan pemecahan masalah dan kemampuan inquiry guru dengan frekwensi relative $20 \%$.

Keterampilan dalam memecahkan suatu masalah, dipandang sebagai produk tindakan yang mampu meningkatkan kemampuan dalam menemukan masalah dan menyelesaikannya, sehingga terlatih untuk menuju berpikir lebih tinggi (Amin Suyitno, 2013). Kemampuan pemecahan masalah merupakan salah satu kemampuan yang harus dimiliki oleh guru. Bagi seorang guru pemecahan masalah berarti tidak hanya menemukan solusi dari masalah, tetapi juga menghadapi situasi baru dan menemukan solusi yang fleksibel, berguna dan elegan terhadap situasi ini (Nasrullah, 2019). Pada dasarnya kemampuan pemecahan masalah berkaitan dengan berbagai skills lain seperti kemampuan mendengar, menganalisa, meneliti, kreativitas, komunikasi, kerja tim, dan pengambilan keputusan. Rendahnya kemampuan pemecahan masalah yang dimiliki oleh seorang guru akan berdampak pada rendahnya kemampuan guru dalam berpikir tingkat tinggi.

To inquiry dalam bahasa Inggris berarti bertanya, meneliti, mengkaji. Dengan demikian inkuiri dapat berarti membaca untuk mencari kebenaran atau pengetahuan dengan jalan bertanya. Dari definisi tersebut dapat disimpulkan bahwa inkuiri adalah proses mencari atau menemukan suatu kebenaran dari informasi yang diketahui. Menurut Trianto (2007) inkuiri sebagai proses yang dilakukan manusia untuk mencari informasi dan pemahaman. Kemampuan inquiry dapat dimanfaatkan untuk menemukan suatu konsep atau aturan. Seseorang yang dapat menemukan sendiri solusi dari masalah yang dihadapinya pasti akan mendapatkan kepuasan tersendiri. Begitupun dalam pembelajaran, dapat menemukan sendiri suatu konsep, rumus dan sejenisnya akan membuat seseorang merasa puas atas usahanya.

Rendahnya kemampuan inquiry seseorang berarti rendahnya kemampuan orang tersebut dalam mencari atau menemukan suatu kebenaran dari informasi yang diketahui. Rendahnya kemampuan inquiry seorang guru akan berimbas pada rendahnya kemampuan guru dalam berpikir tingkat tinggi.

Menurut Potur \& Barkul (2009) mendefinisikan berpikir kreatif adalah sebuah kemampuan kognitif orisinil dan proses memecahkan masalah yang memungkinkan individu menggunakan intelegensinya dengan cara yang unik dan diarahkan menuju pada sebuah hasil. Kemampuan kognitif orisinil ini menekankan pada kemampuan kognitif seseorang untuk menciptakan sesuatu yang unik yang berbeda dengan apa yangdimiliki orang lain.

Berpikir kreatif merupakan kunci dari berpikir untuk merancang, memecahkan masalah, untuk melakukan perubahan dan perbaikan, memperoleh gagasan baru. Sedangkan menurut Al-Khalili (2005) seorang pribadi yang kreatif mampu untuk memberikan kita suatu pemikiran baru atas permasalahanpermasalahan yang dia hadapi atau kita hadapi, baik yang berkaitan dengan kehidupan seharihari atau berkaitan dengan kajian-kajian praktikum. Melalui berpikir kreatif diharapkan juga dapat menyelesaikan masalah dalam kehidupan sehari-hari secara kreatif.

Tingkat kreativitas seorang guru akan menentukan kemampuan guru tersebut dalam memecahkan masalah. Semakin rendah kemampuan kreatif seorang guru maka semakin rendah pula kemampuan pemecahan masalahnya, yang berarti semakin rendah pula kemampuan guru tersebut dalam berpikir tingkat tinggi.

Kemampuan berpikir abstrak adalah kemampuan untuk memproses sebuah informasi yang berkaitan dengan objek, prinsip, dan 
konsep-konsep, yang secara fisik tidak dapat dimunculkan. Kemampuan berpikir abstrak ini bisa dibilang juga sebagai lawan dari kemampuan berpikir konkret. Kalau kemampuan berpikir konkret sangat terikat dengan pemrosesan informasi yang berkaitan dengan objek yang dapat dicerna melalui panca indera, maka kemampuan berpikir abstrak adalah sebaliknya.

Kemampuan berpikir abstrak tidak terlepas dari pengetahuan tentang konsep, karena berpikir memerlukan kemampuan untuk membayangkan atau menggambarkan benda dan peristiwa yang secara fisik tidak selalu ada. Orang yang memiliki kemampuan berpikir abstrak baik akan dapat mudah memahami konsep-konsep abstrak dengan baik. Jadi kemampuan berpikir abstrak adalah kemampuan menemukan pemecahan masalah tanpa hadirnya objek permasalahan itu secara nyata, dalam arti melakukan kegiatan berpikir secara simbolik atau imajinatif terhadap objek permasalahan itu. Untuk menyelesaikan masalah yang bersifat abstrak akan mudah dilakukan oleh orang yang memiliki kemampuan berpikir abstrak yang tinggi dan kemampuan dapat dicapai oleh orang yang sudah mencapai tahap operasional formal yang baik. Guru harus memiliki kemampuan berpikir abstrak yang sangat baik untuk dapat menguasai kemampuan berpikir tingkat tinggi. Untuk mempunyai kemampuan berpikir abstrak yang sangat baik, maka sebelumnya guru harus mempunyai kemampuan pemahaman tentang konsep.

Kemampuan pemahaman sangat diperlukan untuk menguasai materi ajar yang memuat banyak rumus agar siswa dapat memahami konsep-konsep dalam materi tersebut secara utuh serta terampil menggunakan berbagai prosedur didalamnya secara fleksibel, akurat, efisien, dan tepat (Dini, 2018). Tujuan dalam pendidikan yang dikutip oleh Depdiknas dari KTSP (Anita, 2014) yang terdapat pada poin pertama yaitu memahami konsep, menjelaskan keterkaitan antara konsep dan mengaplikasikan konsep secara luwes, akurat, efisien, dan tepat dalam menyelesaikan masalah. Hal tersebut menunjukkan bahwa harus menguasai pemahaman konsep yang pada akhirnya akan menjadi prasyarat dalam menguasai kemampuan yang lainnya. Menurut Mayer (Nuraeni, 2017) pemahaman merupakan aspek yang fundamental dalam pembelajaran. Sehingga dapat dipahami bahwa untuk meningkatkan kemampuan guru berpikir tingkat tinggi maka sebelumnya guru harus membenahi atau meningkatkan kemampuan pemahamannya, yang tentunya juga disertai peningkatan pada kemampuan guru berpikir logis.

Pengertian berpikir logis juga dikemukakan oleh beberapa pakar lainnya (Suryasumantri, Minderovic, Sponias dalam Septiati, 2016), berpikir logis merupakan berpikir menurut pola tertentu atau aturan inferensi logis atau prinsip-prinsip logika untuk memperoleh kesimpulan. Sehingga bisa disimpulkan bahwa kemampuan berpikir logis merupakan kemampuan berpikir menurut pola atau aturan inferensi logis untuk mengambil sebuah kesimpulan. Kemampuan berpikir logis diperlukan individu, pada saat beraktivitas dalam mengambil keputusan, menarik kesimpulan, dan melakukan pemecahan masalah. Bentuk aktivitas yang dilakukan dapat berkaitan dengan masalah matematis maupun masalah yang ditemukan dalam kehidupan sehari-hari. Aktivitas lain yang dilakukan individu dalam berpikir logis adalah ketika menjelaskan mengapa dan bagaimana suatu hasil diperoleh, bagaimana cara menarik kesimpulan dari premis yang tersedia, dan menarik kesimpulan berdasarkan aturan inferensi tertentu. Bentuk aktivitas yang lebih luas dari kemampuan berpikir logis adalah menyelesaikan masalah secara masuk akal.

Peningkatan aktivitas yang lebih luas dari berbagai kemampuan yang telah dibahas diatas harus dilandasi semangat guru untuk mengembangkan diri. Tanpa disertai kemauan guru untuk mengembangkan diri maka aktivitas aktivitas tersebut menjadi sebuah rutinitas belaka.

Pengembangan diri adalah suatu proses pembentukan potensi, bakat, sikap, perilaku dan kepribadian seseorang melalui pembelajaran dan pengalaman yang dilakukan berulang-ulang sehingga meningkatkan kapasitas atau kemampuan diri sampai pada tahap otonomi (kemandirian). Pengembangan diri merupakan suatu upaya seseorang dalam meningkatkan daya saing hidup. Pengembangan diri akan 
mengarahkan manusia untuk menciptakan peradaban. Proses lahirnya sebuah peradaban didasari oleh nilai budaya yang tinggi. Pencipta budaya adalah para intelektual yang didasari oleh pengembangan ilmu dengan benar (Muhammad Aminullah, 2020)

Kemauan pengembangan diri guru ini tentunya akan berimbas pada kualitas dari seorang guru. Kualitas guru adalah tingkatan mutu seorang pendidik dalam memberikan pendidikan dan pembelajaran kepada siswanya guna memenuhi kewenangan dan tanggung jawabnya baik di sekolah maupun di luar sekolah. Menurut mantan Mentri Pendidikan Fuad Hasan, sebaik apapun kurikulum jika tidak dibarengi guru yang berkualitas, maka semuanya sia sia. Sebaliknya kurikulum yang kurang baik akan dapat ditopang oleh guru yang berkualitas (Azhar, 2013)

Dari pembahasan diatas maka diketahui bahwa faktor faktor yang menjadi masalah atau hambatan bagi guru untuk mengembangkan kemampuan berpikir tingkat tinggi adalah rendahnya Kemampuan Pemecahan Masalah, Kemampuan Inquiry, Kemampuan berpikir kreatif, Kemampuan berpikir abstrak, Kemampuan Pemahaman, Kemampuan berfikir logis, Kemauan mengembangkan diri, dan Kualitas Guru.

Faktor - faktor tersebut saling terkait dan terhubung satu dengan yang lain. Sehingga apabila para guru dan pihak yang terkait menginginkan untuk dapat meningkatkan kemampuan guru berpikir tingkat tinggi, maka faktor faktor tersebut haruslah dibenahi terlebih dahulu. Guru harus dapat meningkatkan Kemampuan Pemecahan Masalah, Kemampuan Inquiry, Kemampuan berpikir kreatif, Kemampuan berpikir abstrak, Kemampuan Pemahaman, Kemampuan berfikir logis, Kemauan mengembangkan diri, dan Kualitas Guru agar dapat meningkatkan kemampuan berpikir tingkat tinggi.

\section{KESIMPULAN}

Dari hasil dan pembahasan diatas maka dapat disimpulkan bahwa faktor faktor yang menjadi masalah atau hambatan bagi guru untuk mengembangkan kemampuan berpikir tingkat tinggi adalah rendahnya Kemampuan
Pemecahan Masalah, Kemampuan Inquiry, Kemampuan berpikir kreatif, Kemampuan berpikir abstrak, Kemampuan Pemahaman, Kemampuan berfikir logis, Kemauan mengembangkan diri, dan Kualitas Guru. Untuk dapat meningkatkan kemampuan berpikir tingkat tinggi maka guru harus meningkatkan faktor faktor yang telah disebutkan diatas.

\section{SARAN}

Faktor faktor tersebut diatas saling berkaitan antara satu dengan lainnya. Sehingga disarankan untuk para guru dan pihak yang terkait apabila ingin meningkatkan kemampuan guru untuk berpikir tingkat tinggi maka sebaiknya tidak hanya sekedar mengadakan pelatihan - pelatihan keterampilan berpikir tingkat tinggi. Sebaiknya terlebih dahulu meningkatkan Kemampuan Pemecahan Masalah, Kemampuan Inquiry, Kemampuan berpikir kreatif, Kemampuan berpikir abstrak, Kemampuan Pemahaman, Kemampuan berfikir logis, Kemauan mengembangkan diri, dan Kualitas Guru.

Setelah meningkatkan faktor - faktor tersebut maka dapat diharapkan adanya peningkatan kemampuan guru untuk berpikir tingkat tinggi.

\section{DAFTAR PUSTAKA}

Ade Suryanda, Eka Putri Azrai, Tinia Leyli Shofia Ahmad, Zubaidah, Evi Suryani (2020), Peningkatan Keterampilan Menyusun Soal Berpikir Tingkat Tinggi bagi Guru-Guru Biologi Madrasah Aliyah Negeri Se Jakarta, CEEJ : VOL 1 NO 2 APRIL 2020 E-ISSN : 26866129.

Al-Khalili, A. A. (2005). Mengembangkan Kreativitas Anak. Jakarta: Pustaka AlKautsar.

Amin Suyitno, Endang Sugiharti, (2013), Meningkatkan Kemampuan Memecahkan Masalah Bagi Mahasiswa PGMIPABI Dalam Perkuliahan Telkurmat-2 Melalui PENERAPANMIND-Mapping Berciri Konservasi, Jurnal Penelitian Pendidikan Vol 30 no 12013.

Anita, I. W. (2014). Pengaruh Kecemasan Matematika (Mathematics Anxiety) 
terhadap Kemampuan Koneksi

Matematika (SMP). Infinity Jurnal

Ilmiah, 3(1). Retrieved from ejournal.stkipsiliwangi.ac.id

Azhar, (2013), Pengembangan Instrumen Penilaian Kompetensi Pedagogik Guru Mata Pelajaran Fisika Pada SMA, Jurnal Pendidikan Matematika Volume 4 no 2 Juli 2013

Dina Octaria, (2017), Kemampuan Berpikir Logis Mahasiswa Pendidikan Matematika Universitas PGRI Palembang Pada Mata Kuliah Geometri Analitik.

Dini, M. (2018). Pengaruh Self Confidence Terhadap Kemampuan Pemahman Matematik Siswa SMP. Jurnal Silogisme, 1(3), 1-7.

Dodi Iskandar, Senam (2015), Studi Kemampuan Guru Kimia SMA Lulusan UNY Dalam Mengembangkan Soal UAS Berbasis HOTS, Jurnal Inovasi Pendidikan IPA, Volume 1 Nomor 1, April 2015.

Endah Budi Rahaju, Dini Kinati Fardah, Pradnyo Wijayanti, Ismail, (2020), Kemampuan Guru-guru Matematika SMP Kabupaten Ponorogo dalam mengembangkan soal Berpikir Tingkat Tinggi, Jurnal Pendidikan Matematika Raflesia, Vol. 05 No. 01, Maret 2020.

Femmy Kawuwung, (2011), Profil Guru, Pemahaman Koorperatif NHT, Dan Kemampuan Berpikir Tingkat Tinggi Di SMP Kabupaten Minahasa Utara, ElHayah Vol. 1, No.4 Maret 2011.

Imam Safi'i, Wini Tarmini , Sobri, (2020), Pelatihan Implementasi Pembelajaran Berorientasi pada Keterampilan Berpikir Tingkat Tinggi bagi GuruGuru SMP Negeri 7 Depok, Jawa Barat, Vol. 5, No. 2, 2020, DOI: 10.30653/002.202052.532

Muhammad Aminullah, (2020), Konsep Pengembangan Diri Dalam Menghadapi Perkembangan Teknologi Komunikasi Era 4.0, Komunike, Volume XII, No. 1 Juni 2020

Nasrullah , Rahmah Johar, Said Munzir, (2019), Kemampuan Pemecahan Masalah dan Keyakinan Calon Guru dalam
Menyelesaikan Soal Pemecahan Masalah, Jurnal Pendidikan, Vol. 4, No. 3, Bln Maret, Thn 2019, Hal 346-362

Nuraeni, Evon Siti Mulyati, Rippi Maya, (2018), Analisis Kemampuan Pemahaman Matematis Dan Tingkat Kepercayaan Diri Pada Siswa MTs, Jurnal Pembelajaran Matematika Inovatif, Volume 1, No.5, September 2018

Nuraeni, R, (2017), Perbandingan Kemampuan Pemahaman Matematis Siswa Antara Yang Menggunakan Pembelajaran Inside - Outside - The Comparison Of Students' Mathematical Understanding Between, 6 September 2017, 441-450

Nurul Laila (2019), Meningkatkan Kemampuan Guru IPS Dan PPKn Dalam Menyusun Soal HOTS Melalui Workshop Di Kota Mojokerto, Jurnal Inovasi Pembelajaran, Juni 2019, Vol. 5, No. 2, 19-24.

Septiati, Ety. (2016). Kemampuan Berpikir Logis Matematis Mahasiswa Pendidikan Matematika pada Mata Kuliah Matematika Diskrit. Prosiding Seminar Nasional Pendidikan, Vol. 1 Nomor 1 Th. Jan-Des 2016, halaman. 394-401, ISSN: 2527- 7553.

Yuli Nurul Fauziah (2011), Analisis Kemampuan Guru Dalam Mengembangkan Keterampilan Berpikir Kreatif Siswa Sekolah Dasar Kelas V Pada Pembelajaran Ilmu Pengetahuan Alam, Edisi Khusus No. 2, Agustus 2011.

Yunita Sari, Andarini Permata Cahyaningtyas, Mega Mulianing Maharani, Sari Yustiana, Rida Feronika Kusumadewi, (2019), Meningkatkan kemampuan menyusun soal IPA berorientasi HOTS bagi guru Sekolah Dasar Gugus Pandanaran Dabin IV UPTD Semarang Tengah, Indonesian Journal of Community Services. 